\title{
A rare cause of acute wrist pain: a thrombosed persistent median artery
}

\author{
Akut el bileği ağrısının nadir bir nedeni: Persistan median arter trombozu \\ Elif Nisa Ünlü, ${ }^{1}$ Feray Soyupek, ${ }^{2}$ Ömer Yılmaz, ${ }^{3}$ Aykut Recep Aktaş, ${ }^{3}$ Ural Koç, ${ }^{3}$ Ramazan Büyükkaya ${ }^{1}$ \\ ${ }^{1}$ Department of Radiology, Medical Faculty of Düzce University, Düzce, Turkey \\ ${ }^{2}$ Department of Physical Medicine and Rehabilitation, Medical Faculty of Süleyman Demirel University, Isparta, Turkey \\ ${ }^{3}$ Department of Radiology, Medical Faculty of Süleyman Demirel University, Isparta, Turkey
}

Received / Geliş tarihi: January 2014 Accepted / Kabul tarihi: August 2014

\begin{abstract}
The persistent median artery (PMA) is an anatomic variation of the hand vascularity and is usually asymptomatic. The presence and thrombosis of PMA may result in several complications such as carpal tunnel syndrome. Early diagnosis and treatment of acute thrombosis of PMA is important because many complications and the need for surgery can be prevented with early anticoagulant therapy. In this report, we present the imaging findings of a thrombosed PMA causing acute wrist pain in a 36-year-old female case. Early anticoagulant therapy provided complete resolution of the symptoms. She had any evidence of carpal tunnel syndrome or another complication.
\end{abstract}

Keywords: Persistent median artery; thrombosis; wrist pain.

\section{$\ddot{O Z Z}$}

Persistan median arter (PMA), elin vasküler yapısının anatomik bir varyasyonudur ve genellikle asemptomatiktir. Persistan median arterin varlığ 1 ve trombozu, başta karpal tünel sendromu olmak üzere çeşitli komplikasyonlara yol açabilmektedir. Akut PMA trombozunun erken tanı ve tedavisi önemlidir; zira erken antikoagülan tedavi ile birçok komplikasyon ve cerrahi gereksinimi önlenebilmektedir. Bu yazıda, 36 yaşında bir kadın olguda akut el bileği ağrısına neden olan tromboze PMA'nın görüntüleme bulguları sunuldu. Erken antikoagülan tedavi, semptomların tamamen iyileşmesini sağladı. Hastada karpal tünel sendromu veya başka bir bulgusu yoktu.

Anahtar sözcükler: Persistan median arter; tromboz; el bileği ağrisı.

The vascular supply of the hand is variable and the persistent median artery (PMA) is one of the numerous variations. ${ }^{[1]}$ This anatomic variation is seen in approximately $10 \%$ of the normal population ${ }^{[2]}$ and is almost always asymptomatic. Thrombosis of PMA is very rare and a few case reports for thrombosis and related complications are presented in the literature, but the real incidence of PMA thrombosis is not well known. Thrombosis of PMA can cause some emergency complications such as acute carpal tunnel syndrome (CTS) or digital ischemia. ${ }^{[2-6]}$ The aim of this article was to present the imaging findings of acute thrombosis of a PMA as a cause of acute wrist pain without another abnormality in a young female and to discuss the case in light of the pertinent literature.

\section{CASE REPORT}

A 36-year-old female was admitted to the physical medicine and rehabilitation clinic with the sudden onset of severe pain in her left (non-dominant) wrist two days ago. The pain radiated to fingers and elbow. Wrist pain was aggravated by motion. She experienced no paresthesia, weakness or nocturnal pain. Past medical history did not include any trauma, drug use, alcohol use or chronic disease such as hypercoagulopathy or diabetes, but she was a smoker. Inspection of the volar and dorsal aspects of the hand was normal. No nodules were palpated. Soft tissues were not swollen. She had only hypersensitivity on the volar aspect of her wrist. The range of motion was not restricted. Phalen,

Corresponding author / İletişim adresi: Elif Nisa Ünlü, MD. Düzce Üniversitesi Tıp Fakültesi Radyoloji Anabilim Dalı, 81000 Konuralp Yerleşkesi, Düzce, Turkey. e-mail / e-posta: nisaunlu@yahoo.com 

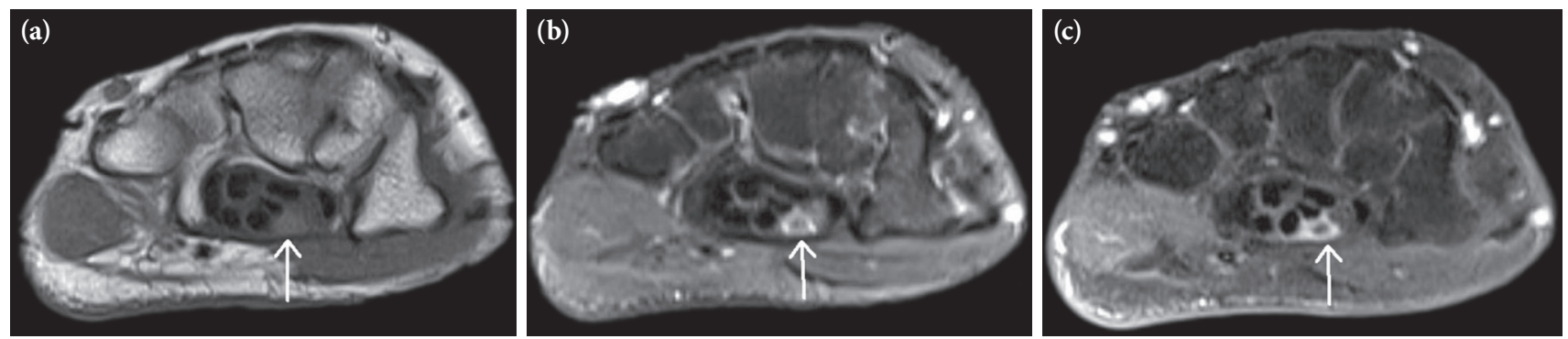

Figure 1. (a) Transverse $T_{1}$ weighted, (b) fat-sat $T_{2}$ weighted and (c) postcontrast fat-sat $T_{1}$ weighted images of magnetic resonance imaging show the thrombosed artery on the ulnar side of the median nerve in the carpal tunnel (arrows).

Tinel, Finkelstein tests were negative. The neurological examinations of the hand including sensation and motor function tests were normal. X-ray and laboratory tests were normal. Magnetic resonance imaging (MRI) was performed with a suspicion of avascular necrosis of the lunatum. Magnetic resonance imaging showed a round tubular structure on the ulnar side of median nerve in the carpal tunnel, which is mild hyperintense compared to median nerve on $\mathrm{T}_{1}$ weighted images and hypointense with hyperintense rim on $\mathrm{T}_{1}$ weighted and fat-saturated $\mathrm{T}_{2}$ weighted images. After contrast injection, rim enhancement with a central filling defect is seen (Figure 1). Ultrasonography (US) and Doppler examination revealed the artery with focal dilatation and thrombus in the carpal tunnel, presented as a segment with loss of signal flow. Computed tomography angiography (CTA) of forearm and hand was performed for best evaluation of the artery and its origin. The artery was arising proximally from the ulnar artery (Figure 2). Computed tomography angiography also showed the focal occlusion of the artery. The median nerve was mild hyperintense on $\mathrm{T}_{2}$ weighted images in the carpal tunnel. However electromyography (EMG) showed no abnormality. Physical examination and bilateral arterial and venous Doppler US examinations of upper and lower extremities were performed to exclude cardiovascular diseases. No abnormality was detected. The patient underwent anticoagulant therapy two days after admission and improved symptomatically. The therapy included subcutaneous enoxaparin sodium $0.6 \mathrm{~mL}$ twice daily for two weeks. A follow-up US and Doppler examination after two weeks showed recanalization of the lumen and decrease in diameter of the affected artery. The patient had no further pain. Acetylsalicylic acid was given $100 \mathrm{mg}$ a day for six months for prophylaxis. Pre- and posttreatment US and Doppler US findings are shown in Figure 3 and 4. A written informed consent was obtained from the patient.

\section{DISCUSSION}

The median artery usually regresses after the eighth week of gestation but in rare cases it persists into adulthood. ${ }^{[7]}$ The presence of a PMA may result in several complications such as CTS, digital ischemia, pronator syndrome, or anterior interosseous nerve syndrome..$^{[3-6,8]}$ A large PMA, an aneurysm, thrombosis or traumatic

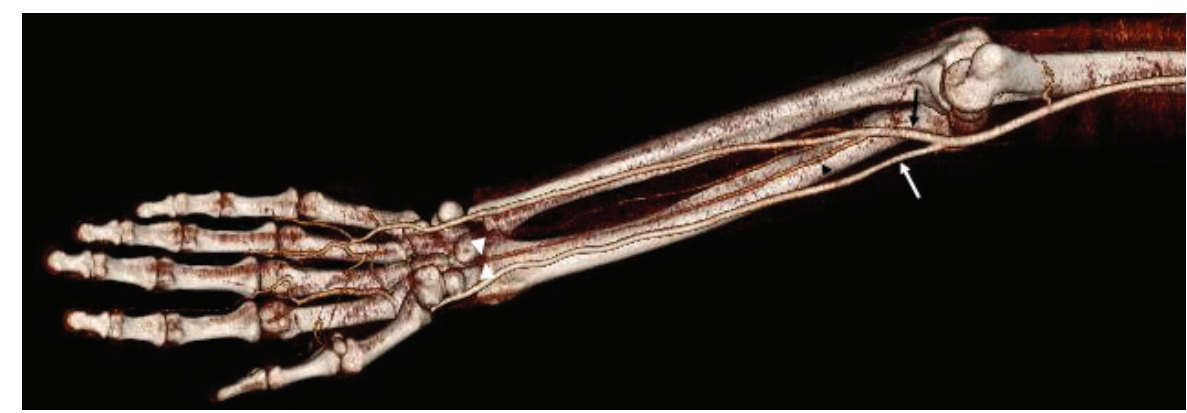

Figure 2. Computed tomography angiography of the forearm and hand shows the origin of the persistent median artery (grey arrowhead). The artery arises proximally from the ulnar artery (grey arrow). Radial artery is shown as the white arrow. Persistent median artery is invisible at the level of wrist because of occlusion (beginning of the occlusion is shown as white arrowheads). 

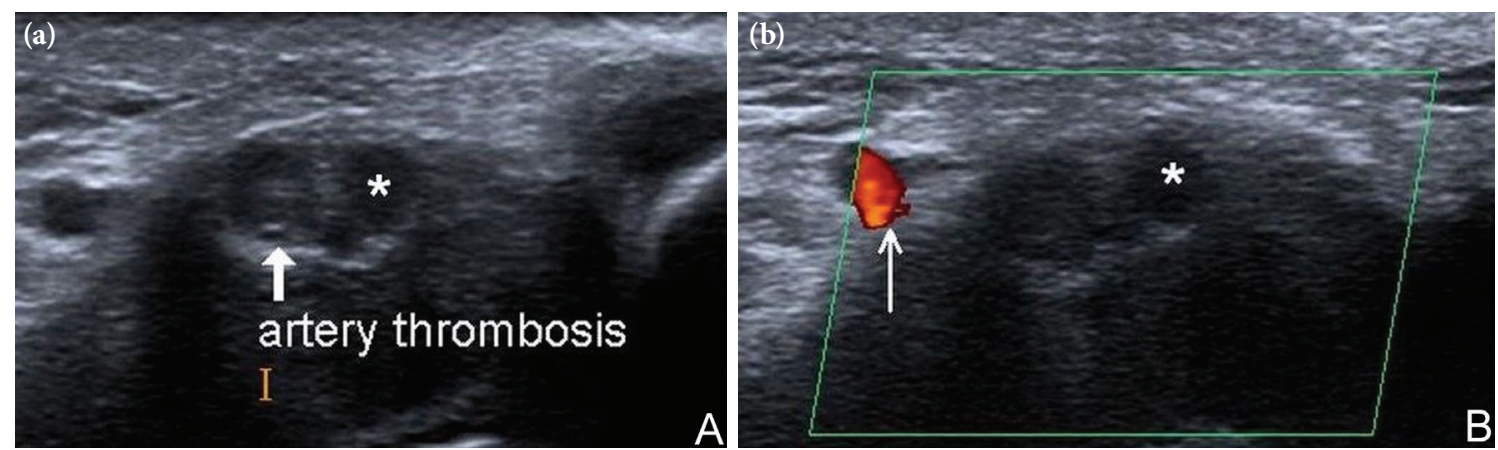

Figure 3. (a) Transverse ultrasound image of the carpal tunnel shows the thrombosed artery (arrow) next to the median nerve $\left(^{*}\right)$ and (b) color Doppler shows loss of signal flow in the persistent median artery. Presence of flow in the ulnar artery is also noted (thin arrow).

rupture of such an artery may cause CTS. Persistent median artery may cause damage to the median nerve in two ways: (i) compression and (ii) ischemia. ${ }^{[8]}$ We could not identify any complications of PMA except wrist pain in this case. However we detected mild hyperintensity in the median nerve on fat-saturated $\mathrm{T}_{2}$ weighted images of MRI in the carpal tunnel, there was no evidence of CTS in electrodiagnostic test and on physical examination. The compression was not enough to block the signal transmission of the myelin sheaths.

Causes such as infection of deep fascial planes due to a cut, frequent bicycle riding with an unusual position of the wrist, trauma, repeated stretch and vibration from a stiff clutch of motorcycle, oral contraceptives, screwdriver usage and excessive housework have been described for thrombosis of PMA. ${ }^{[3,5]}$ Our case had no such history. Because of lack of another reason, smoking came to mind as a predisposing factor for our patient, however she did not have any other vascular abnormality. Persistent median artery has been found both unilaterally and bilaterally. Consistent with our case, D'Costa et al. ${ }^{[9]}$ found that the incidence of PMA on the left hand was double that on the right hand. Whereas Rodríguez-Niedenführ et al. ${ }^{[10]}$ found no significant difference between right and left side.

Treatment options include surgery and medical therapy. The decompression of the carpal tunnel and dissection of the artery are recommended as the surgical treatments of CTS. The excision of the thrombosed segment of the artery is considered possible after ensuring a sufficient blood supply to the fingers. ${ }^{[3,8]}$ There is no special medical treatment protocol for PMA thrombosis. In cases without CTS, anticoagulant therapy and thrombosis prophylaxis
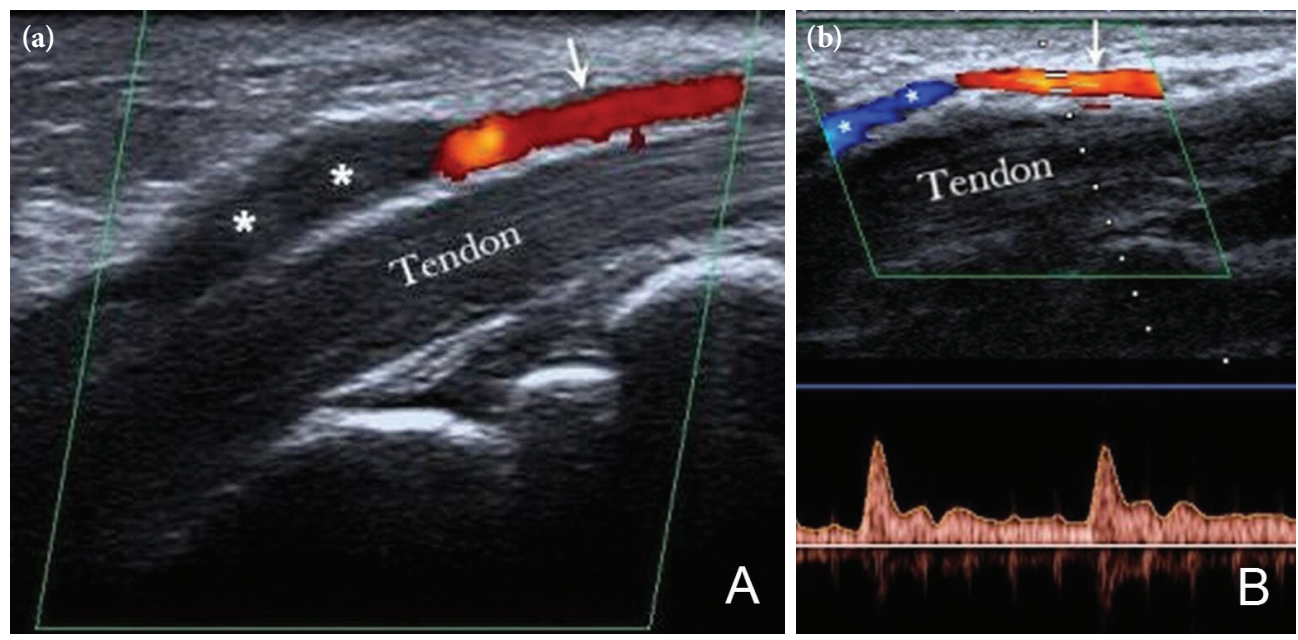

Figure 4. (a) Longitudinal section of the persistent median artery with color flow mapping shows dilated and occluded segment of the artery (asterisks) and presence of flow proximally (arrow). (b) Pulse Doppler after anticoagulant therapy shows filling of the signal flow (asterisks) and improving spectral flow pattern and velocities. 
can be used as in our case. Physicians should decide the dose and duration of treatment according to the patient's clinical status.

In conclusion, thrombosed PMA should be kept in mind in the differential diagnosis of acute wrist pain. Careful physical examination and radiological experience is necessary for evaluation and correct diagnosis of these cases. In the presence of clinical suspicion, we recommend US and Doppler examination as a first step, because these techniques are simple, inexpensive, widely available and noninvasive. Early detection of thrombosis helps to start early anticoagulant therapy and prevents the need for surgery or thrombolytics and also early detection may prevent CTS or other complications.

\section{Declaration of conflicting interests}

The authors declared no conflicts of interest with respect to the authorship and/or publication of this article.

\section{Funding}

The authors received no financial support for the research and/or authorship of this article.

\section{REFERENCES}

1. Lisanti M, Rosati M, Pardi A. Persistent median artery in carpal tunnel syndrome. Acta Orthop Belg 1995;61:315-8.
2. Beran SJ, Friedman RM, Kassir M. Recurrent digital ischemia due to thrombosis of the persistent median artery. Plast Reconstr Surg 1997;99:1169-71.

3. Salter M, Sinha NR, Szmigielski W. Thrombosed persistent median artery causing carpal tunnel syndrome associated with bifurcated median nerve: A case report. Pol J Radiol 2011;76:46-8.

4. Kele H, Verheggen R, Reimers CD. Carpal tunnel syndrome caused by thrombosis of the median artery: the importance of high-resolution ultrasonography for diagnosis. Case report. J Neurosurg 2002;97:471-3.

5. Khashaba A. Carpal tunnel syndrome from thrombosed persistent median artery. J Emerg Med 2002;22:55-7.

6. Balakrishnan C, Smith MF, Puri P. Acute carpal tunnel syndrome from thrombosed persistent median artery. J Emerg Med 1999;17:437-9.

7. Singer E. Embriyological pattern persisting in the arteries of the arm. Anatomic Record 1933;55:403-9.

8. Natsis K, Iordache G, Gigis I, Kyriazidou A, Lazaridis $\mathrm{N}$, Noussios G, et al. Persistent median artery in the carpal tunnel: anatomy, embryology, clinical significance, and review of the literature. Folia Morphol (Warsz) 2009;68:193-200.

9. D'Costa S, Narayana K, Narayan P, Nayak SR, Madhan SJ. Occurrence and fate of palmar type of median artery. ANZ J Surg 2006;76:484-7.

10. Rodríguez-Niedenführ M, Sañudo JR, Vázquez T, Nearn L, Logan B, Parkin I. Median artery revisited. J Anat 1999;195:57-63. 